\title{
INFLUENCE OF LONG-TERM FERTILIZATION ON YIELD AND QUALITY OF SPRING TRITICALE GRAIN
}

\author{
Hryhorii Hospodarenko, *Vitalii Liubych \\ Uman National University of Horticulture, Ukraine \\ *Corresponding author’s email: LyubichV@gmail.com
}

\begin{abstract}
Triticale $(\times$ Triticosecale Wittmack) is a promising cereal crop that has a number of economically valuable properties that are absent in wheat (Triticum aestivum L.). The research was conducted at Uman National University of Horticulture (Ukraine) in a long-term stationary experiment, founded in 1964. The aim of the work was to study the influence of long-term application of different fertilizer systems (mineral, organic and organo-mineral) on the yield and grain quality of spring triticale. It has been established that in the conditions of high air temperature and soil moisture deficit, mineral and organo-mineral fertilizer systems have an advantage. In sufficient wet conditions, all studied fertilizer systems are highly efficient. Spring triticale (Kharkiv Hlibodar variety) has a high reaction to fertilizers, as grain yield increases from 6.3-6.6 to $9.0-9.5 \mathrm{t} \mathrm{ha}^{-1}$ ( $\mathrm{p} \leq 0.05$ ). Mineral and organo-mineral fertilizer systems have the greatest effect on protein content. In conditions of sufficient moisture, all levels of mineral and organo-mineral fertilizer systems significantly increase the protein content in spring triticale grain. In arid conditions, saturation of crop rotation area with $\mathrm{N}_{90} \mathrm{P}_{90} \mathrm{~K}_{90}(\mathrm{M} 2), \mathrm{N}_{135} \mathrm{P}_{135} \mathrm{~K}_{135}$ (M3) and Manure $9 \mathrm{t}+\mathrm{N}_{46} \mathrm{P}_{68} \mathrm{~K}_{36}$ (OM2), Manure $13.5 \mathrm{t}+\mathrm{N}_{69} \mathrm{P}_{102} \mathrm{~K}_{54}(\mathrm{OM} 3)$ is preferred. It should be noted that spring triticale is quite reactive with fertilizers, as the protein content increases from $13.2-14.0$ to $15.2-16.0 \%(\mathrm{p} \leq 0.05)$ depending on the fertilizer system. The high influence of fertilizer system and year factors on yield and protein content in triticale grain has been established. It should be noted that spring triticale grain yield varies most from the weather conditions of the growing season.
\end{abstract}

Key words: spring triticale, long-term fertilization, yield, quality.

\section{Introduction}

According to Eurostat (FAOSTAT data, 2020 March, available at: http://www.fao.org/faostat/ en/\#data/QC), the gross production of cereals is about 300 million tons per year. Currently, the main crop is soft wheat (Triticum aestivum L.) (Kiseleva et al., 2016). However, world production of triticale $(\times$ Triticosecale Wittmack $)$ is more than 20 million tons per year, half of which falls on Germany and Poland. Triticale has a number of economically valuable properties that are absent in wheat. They are: fast growth force of green matter, high cold resistance, the higher protein content in grain and average baking properties. Triticale usually grows well under abiotic stress compared to wheat (Furman, 2016). In addition, triticale is characterized by high resistance to major fungal diseases (Liubych et al., 2020). However, the plants are not resistant to Claviceps purpurea (Fr.) Tul. (Furman, 2016).

Triticale is a highly productive grain crop. Grain yield can be 7-8 $\mathrm{t} \mathrm{ha}^{-1}$ (Liubych, 2019). The crop is highly reactive with fertilizers (Lalević et al., 2019). Triticale grain is used for food and fodder purposes (green fodder, silage, haylage, hay). In addition, it is also an energy crop (Karl, 2017). Triticale grain is a promising raw material for the production of high quality cereal products (Liubych et al., 2020). Triticale flour is used to replace rye (Oryza sativa L.) one in the recipe of wheat and rye bread. The soft-grained varieties of triticale are used to make waffles. Triticale flour has no specific properties and recommendations that differ from wheat one (Wrigley \& Bushuk, 2017). In addition, the grain of this crop is suitable for the production of a number of products: cakes, cookies, cupcakes, waffles, noodles and spaghetti (Salmon, Mergoum, \& Macpherson, 2004). Therefore, research to increase triticale productivity is relevant.

The use of triticale fertilizers has some features. Fertilizer efficiency also depends on soil type, preceding crop, weather conditions of the growing season, variety potential, etc. (Darguza \& Gaile, 2020). Nitrogen in interaction with other elements of mineral nutrition plays a significant role in triticale yield and quality. Plant nutrition with nitrogen has a great influence on the yield and grain quality of triticale (Dekic et al., 2014). To form the high yield and grain quality, it is necessary to provide plants with nitrogen throughout the growing season. However, the use of nitrogen fertilizers, especially high doses, can contribute to environmental pollution, which should be taken into account when developing a fertilizer system for this crop (Nikolic et al., 2012). The research results (Terzic et al., 2018) showed that triticale changes the reaction to intensive nitrogen nutrition in different agroecological conditions. In Serbia, the highest yield was obtained using $120 \mathrm{~kg} \mathrm{~N} \mathrm{ha}^{-1}, 60 \mathrm{~kg} \mathrm{P}_{2} \mathrm{O}_{5} \mathrm{ha}^{-1}$ and $60 \mathrm{~kg} \mathrm{~K}_{2} \mathrm{O} \mathrm{ha}{ }^{-1}$ for three years of research. In these researches, it was found that triticale grain yield can vary from 2.06 to $4.29 \mathrm{t} \mathrm{ha}^{-1}$ depending on weather conditions. The strong influence of weather conditions on the efficiency of triticale fertilizer was statistically confirmed. However, these researches did not include the use of organic and organo-mineral fertilizers.

Nitrogen fertilizers are one of the biggest factors influencing the formation of grain yield of cereals and its quality (Novak et al., 2019). In researches 
(Litke, Gaile, \& Ruža, 2017) the use of N120(90+30) and $\mathrm{N} 150(90+60)$ increased the grain yield of winter wheat from 4.83 to $8.71-9.11 \mathrm{tha}^{-1}$ per cultivation after winter rape. Increasing the dose of nitrogen fertilizers to N180-240 did not significantly increase this indicator. The efficiency of winter wheat fertilization in the experiment varied from other elements of agricultural technology. However, the research did not include the study of grain productivity formation in the field crop rotation with long-term fertilization, which does not allow to determine crop reaction to the level of soil fertility. In addition, the study was conducted with winter wheat, the fertilizer of which differs from spring triticale.

Researches by other scientists have shown high efficiency of nitrogen fertilizers in spring triticale cultivation. However, studies were performed with the forage variety, so the optimal dose was the use of $\mathrm{N}_{56}$ (Obour, Holman, \& Schlegel, 2020). Given the insufficient study of spring triticale reaction at the soil fertility level of podzolic chernozem, created by long-term use of fertilizers in the field crop rotation, research is relevant.

The aim of the work was to study the influence of the long-term application of different fertilizer systems (mineral, organic and organo-mineral) on the yield and grain quality of spring triticale.

\section{Materials and Methods}

The research was performed in the field conditions of Uman National University of Horticulture during 2007-2009 in the stationary experiment of the Department of Agrochemistry and Soil Science. The experiment was launched in 1964, and it is based on a 10-field crop rotation extended in time and space (spring triticale + meadow clover (Trifolium pretense L.), meadow clover, winter wheat, sugar beet (Beta vulgaris L. saccharifera), maize (Zea mays L.), peas (Pisum sativum L.), winter wheat, silage maize, winter wheat, sugar beet). The efficiency of fertilizer systems was studied on 10 backgrounds (average saturation of crop rotation area with fertilizers) - without fertilizers (control), $\mathrm{N}_{45} \mathrm{P}_{45} \mathrm{~K}_{45}$ (M1), $\mathrm{N}_{90} \mathrm{P}_{90} \mathrm{~K}_{90}$ (M2), $\mathrm{N}_{135} \mathrm{P}_{135} \mathrm{~K}_{135}$ (M3), Manure $9 \mathrm{t}(\mathrm{O} 1)$, Manure $13.5 \mathrm{t}(\mathrm{O} 2)$, Manure $18 \mathrm{t}(\mathrm{O} 3)$, Manure $4.5 \mathrm{t}+\mathrm{N}_{23} \mathrm{P}_{34} \mathrm{~K}_{18}$ (OM1), Manure 9 $\mathrm{t}+\mathrm{N}_{46} \mathrm{P}_{68} \mathrm{~K}_{36}(\mathrm{OM} 2)$, Manure 13.5 $\mathrm{t}+\mathrm{N}_{69} \mathrm{P}_{102} \mathrm{~K}_{54}(\mathrm{OM} 3)$. Fertiliser rates were applied in the form of half-rotted cattle straw manure, ammonium nitrate, granulated superphosphate, mixed potassium salt and potassium chloride. The total area of the plot was $180 \mathrm{~m}^{2}$, the experimental plot covered $100 \mathrm{~m}^{2}$, the experiment was repeated three times on the same location. 'Kharkiv Hlibodar' spring triticale variety was used in the experiment.

The experimental plot was located in Mankivka natural-and-agricultural district of the MiddleDnieper-Buh district of the Forest-Steppe Right-Bank province of the Forest-Steppe zone with geographical coordinates of $48^{\circ} 46^{\prime} 56,47^{\prime \prime}$ of north latitude and $30^{\circ} 14^{\prime} 48,51$ ' of east longitude by Greenwich. Height above sea level was $245 \mathrm{~m}$. The soil of the experimental field was podzolized chernozem. Before the experiment the soil was under a longterm cultivation under field crops. Soil samples taken before the experiment (1964) had the following parameters: content of physical clay $-66.5 \%$, base saturation $-95 \%$, humus content $-3.31 \%$; content of easily hydrolysable organic nitrogen (according to the Tjurin-Kononova method); mobile compounds of phosphorus and potassium (according to Chirikov method) - 122 and $135 \mathrm{mg} \mathrm{kg}^{-1}$ respectively; $\mathrm{pH}_{\mathrm{KCl}}-$ 6.2. Soil was characterized by such indicators at the time of setting up the experiment.

The protein content was determined by the method of infrared spectroscopy using Infratek 1241. Statistical data processing was performed using STATISTICA 10. Interpretation of the influence level by partial coefficient (thumb rule - Cohen): $0.02-0.13$ - weak, $0.13-0.26$ - medium, $\geq 0.26$ - high. The null hypothesis was confirmed or refuted during the performing of variance analysis. The p-value was determined for this purpose, which showed the probability of the corresponding hypothesis. In cases, where $\mathrm{p}<0.05$, 'the null hypothesis' was refuted and the influence of the factor was significant.

The timing of sowing and harvesting of spring triticale varied depending on weather conditions (Table 1). The higher air temperature in 2007 contributed to the earlier sowing and harvesting of spring triticale. In 2008 and 2009, sowing and harvesting were typical for the Right-Bank forest-steppe zone.

The characteristic feature of 2007 (Table 2) was the increase in air temperature, low rainfall and drought, which lasted from May to July. Thus, during April-July period, only $92.9 \mathrm{~mm}$ of precipitation fell, which is 3.4 times less than the long-term average.

Table 1

Spring triticale sowing and harvesting time date in spring during trial years

\begin{tabular}{|l|c|c|c|}
\hline \multirow{2}{*}{\multicolumn{1}{|c|}{ Indicators }} & \multicolumn{3}{|c|}{ Year of research } \\
\cline { 2 - 4 } & 2007 & 2008 & 2009 \\
\hline Sowing time & March $17^{\text {th }}$ & March $29^{\text {th }}$ & April $7^{\text {th }}$ \\
\hline Harvesting time & June $30^{\text {th }}$ & July $22^{\text {th }}$ & July $19^{\text {th }}$ \\
\hline
\end{tabular}


Weather conditions at the experimental site

\begin{tabular}{|l|c|c|c|c|c|c|c|c|}
\hline \multirow{3}{*}{ Month } & \multicolumn{9}{|c|}{ Year } \\
\cline { 2 - 10 } & 2007 & 2008 & 2009 & $1961-1990$ & 2007 & 2008 & 2009 & $1961-1990$ \\
\cline { 2 - 10 } & \multicolumn{3}{|c|}{ Precipitation (mm) } & \multicolumn{5}{c|}{ Temperature $\left({ }^{\circ} \mathrm{C}\right)$} \\
\hline March & 12.8 & 49.6 & 46.8 & 39.0 & 5.5 & 4.6 & 2.2 & 0.4 \\
\hline April & 10.0 & 54.5 & 0.0 & 48.0 & 8.5 & 10.0 & 10.1 & 8.5 \\
\hline May & 6.5 & 33.7 & 38.5 & 55.0 & 18.4 & 13.9 & 14.6 & 14.6 \\
\hline June & 35.3 & 51.2 & 49.0 & 87.0 & 20.9 & 18.6 & 20.2 & 17.6 \\
\hline July & 28.3 & 44.7 & 86.1 & 87.0 & 23.0 & 21.1 & 21.2 & 19.0 \\
\hline
\end{tabular}

This resulted in the lowest yield of spring triticale. Weather conditions in 2008 were more favourable for the growth and development of spring triticale although during the growing season $233.7 \mathrm{~mm}$ of precipitation fell, which is 1.4 times less than the average long-term amount. Weather conditions in 2009 were characterized by uneven distribution of precipitation during the spring triticale vegetation and a slow increase in heat at the beginning of the growing season. April was dry and warm, the moisture in a meter layer of soil was enough to get even sprouts. In general, weather conditions contributed to the high yield of spring triticale although $220.4 \mathrm{~mm}$ of precipitation fell in April-July, which is 1.4 times less than the long-term average.

Characteristics of Kharkiv Khlibodar spring triticale variety. Applicant and owner is V. Ya Yuryev Institute of Plant Breeding. The variety is hexaploid. The type of development is spring. Anthocyanin colour of the seedlings is medium. The bush is semistraight. The stem is medium-sized with very strong pubescence near the ear. The ear is white, long, of medium density. The awns are long, located along the entire length of the ear. The kernel is red, large. Weight of 1000 grains is $40.0 \mathrm{~g}$. Plants are $114-117 \mathrm{~cm}$ high. It is medium-ripe, ripens for 96-97 days. Variety lodging resistance is 7.6 points, drought resistance is 8.0 points. The variety is weakly affected by powdery mildew, brown rust and root rot. It is recommended for the Forest-Steppe and Polissia of Ukraine.

\section{Results and Discussion}

The research results show that all fertilizer systems significantly increased the yield of spring triticale grain compared to the variant without fertilizers $(p \leq 0.05)$ (Figure 1). The lowest fertilizer efficiency was established in 2007. Thus, the grain yield of spring triticale under the mineral fertilizer system increased by 1.3-1.7 times (2.7-3.5 $\left.\mathrm{t} \mathrm{ha}^{-1}\right)$, and that of the organic system by $1.1-1.2\left(2.4-2.6 \mathrm{t} \mathrm{ha}^{-1}\right)$, organo-mineral system $-1.2-1.6$ times $\left(2.6-3.3 \mathrm{t} \mathrm{ha}^{-1}\right)$ depending on the level of crop rotation saturation with fertilizers. In 2008, this indicator increased by 1.2 1.5 times (7.7-9.5 $\mathrm{t} \mathrm{ha}^{-1}$ ) depending on the fertilizer system and the level of crop rotation area saturation. A similar tendency in the formation of the spring triticale crop was established in 2009.

It should be noted that in the best years in terms of precipitation distribution, the variants of the mineral and organo-mineral fertilizer systems significantly increased the grain yield between the levels of crop rotation area saturation. The application of manure in field crop rotation had different efficiency. Thus, the average saturation of crop rotation area with manure at a dose of $13.5 \mathrm{tha}^{-1}(\mathrm{O} 2)$ and $18.0 \mathrm{t} \mathrm{ha}^{-1}(\mathrm{O} 3)$ did not significantly affect the grain yield of spring triticale compared to Manure $9 \mathrm{t} \mathrm{ha}^{-1}(\mathrm{O} 1)$ variant in 2007. In 2008, the variant with average manure saturation at a dose of $13.5 \mathrm{t} \mathrm{ha}^{-1}$ was significantly higher in yield compared to a single dose. In 2009, even the saturation of $18.0 \mathrm{t} \mathrm{ha}^{-1}$ with manure significantly increased compared to the Manure $13.5 \mathrm{t} \mathrm{ha}^{-1}$ variant.

In conditions of moisture deficiency, the efficiency of mineral and organo-mineral fertilizers is higher compared to the organic system. In years with the best distribution of precipitation, the efficiency of the mineral and organo-mineral fertilizer system is the same. The efficiency of the organic fertilizer system is not stable: in 2008, the yield was significantly lower than in other fertilizer systems, and in 2009 it was at their level.

The effect of long-term application of fertilizers in field crop rotation on spring triticale grain yield was different depending on weather conditions. In the dry year of 2007, this indicator was the lowest. It should be noted that the organic system was less efficient as a result of deteriorating conditions of soil organic matter mineralization. The formation of significantly lower yield of spring triticale in the organic system in 2008 is due to the use of nutrients from the previous crop. In 2009, this phenomenon did not exist, so grain yield was at the level of other fertilizer systems. The 


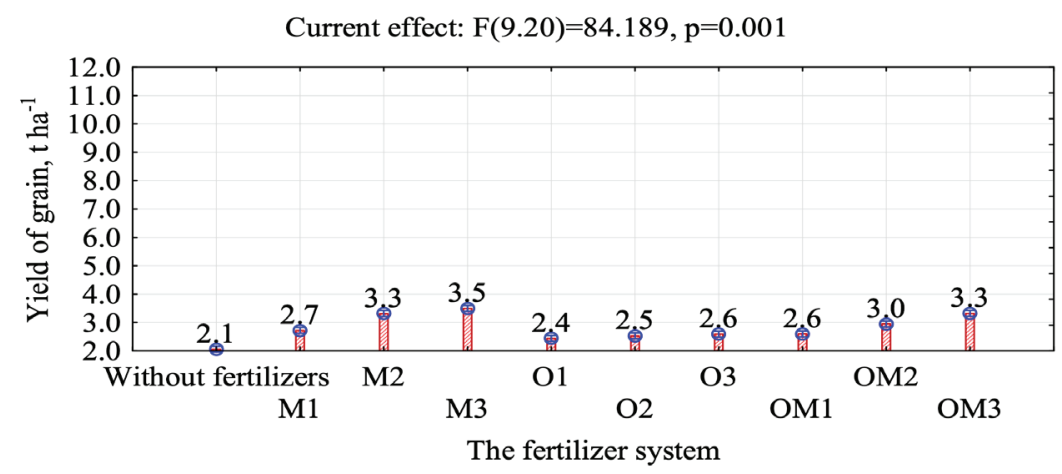

2008

Current effect: $F(9.20)=1671.7, p=0.001$

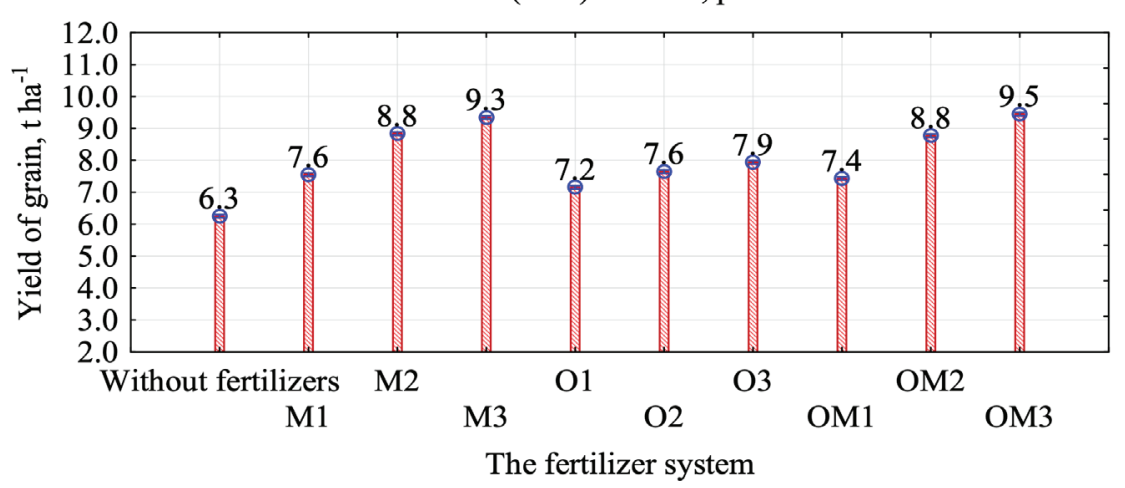

2009

Current effect: $F(9.20)=952.92, p=0.001$

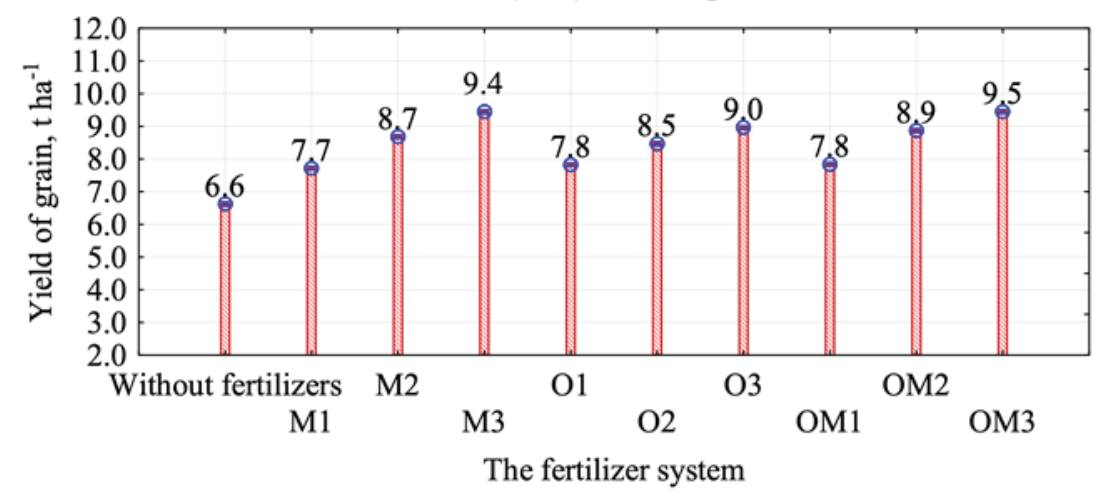

Figure 1. Spring triticale grain yield depending on fertilizer and trial year, $\mathrm{t} \mathrm{ha}^{-1}$ : Without fertilizer - control; $\mathrm{M} 1-\mathrm{N}_{45} \mathrm{P}_{45} \mathrm{~K}_{45}, \mathrm{M} 2-\mathrm{N}_{90} \mathrm{P}_{90} \mathrm{~K}_{90}, \mathrm{M} 3-\mathrm{N}_{135} \mathrm{P}_{135} \mathrm{~K}_{135}, \mathrm{O} 1$ - Manure $9 \mathrm{t}$, O2 - Manure $13.5 \mathrm{t}, \mathrm{O} 3$ - Manure $18 \mathrm{t}$, OM1 - Manure $4.5 \mathrm{t}+\mathrm{N}_{23} \mathrm{P}_{34} \mathrm{~K}_{18}, \mathrm{OM} 2$ - Manure $9 \mathrm{t}+\mathrm{N}_{46} \mathrm{P}_{68} \mathrm{~K}_{36}, \mathrm{OM} 3$ - Manure $13.5 \mathrm{t}+\mathrm{N}_{69} \mathrm{P}_{102} \mathrm{~K}_{54}$.

obtained tendencies are similar to the results given in the works of other scientists. Thus, in the long-term field experiment, the effectiveness of fertilization for winter wheat significantly changed depending on the precursor and fertilizer system. Scientists statistically obtained a higher yield for the application of $\mathrm{N}_{135} \mathrm{P}_{30} \mathrm{~K}_{100}+5 \mathrm{t} \mathrm{ha}^{-1}$ organic fertilizer $-7.15 \mathrm{tha}^{-1}$. The use of $\mathrm{N}_{135} \mathrm{P}_{30} \mathrm{~K}_{100}$ increased this indicator to only
$6.65 \mathrm{t} \mathrm{ha}^{-1}$ for cultivation after pea precursor. The use of such a fertilization system of winter wheat for growing after the winter barley precursor, grain yield was significantly lower than pea precursor. The yield also varied with the weather conditions of the study year. Thus, this indicator varied from 5.98 to $8.29 \mathrm{t} \mathrm{ha}^{-1}$ for cultivation after pea and from 4.94 to $6.93 \mathrm{t} \mathrm{ha}^{-1}-$ after winter barley. It should be noted that the share of 


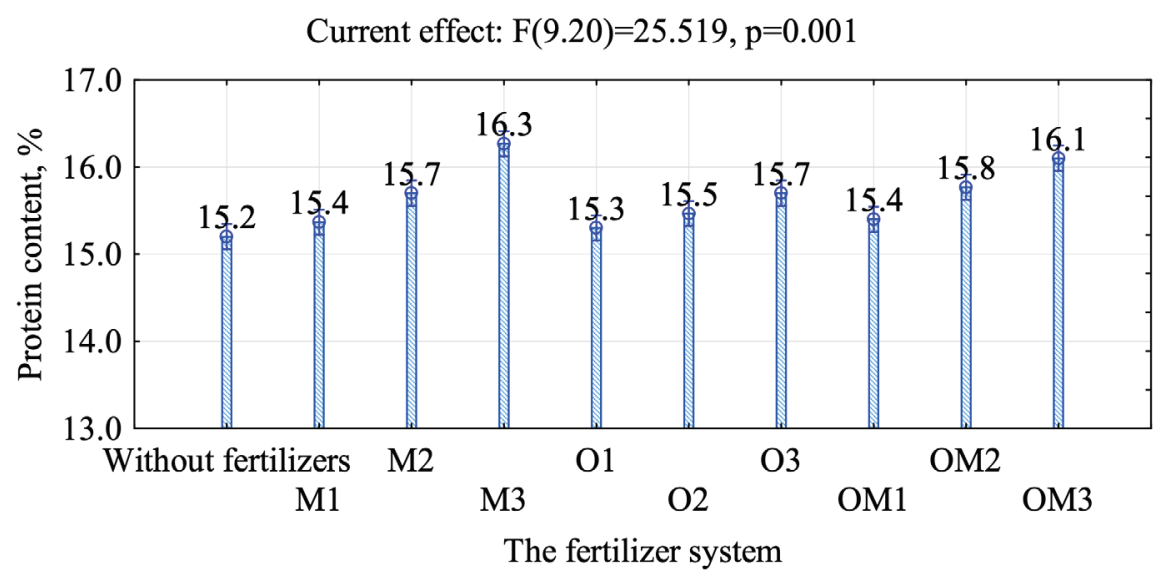

2008

Current effect: $F(9.20)=55.530, p=0.001$

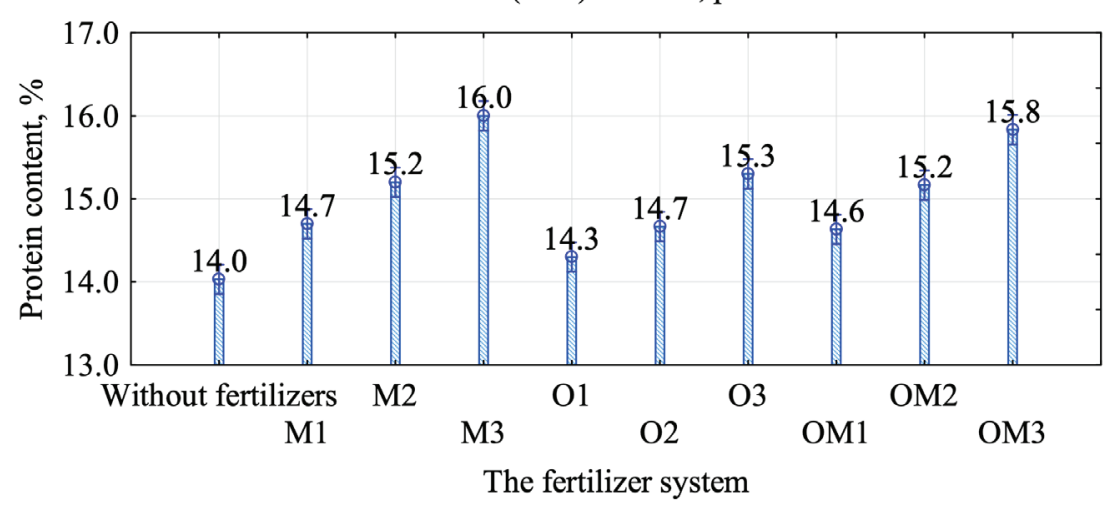

2009

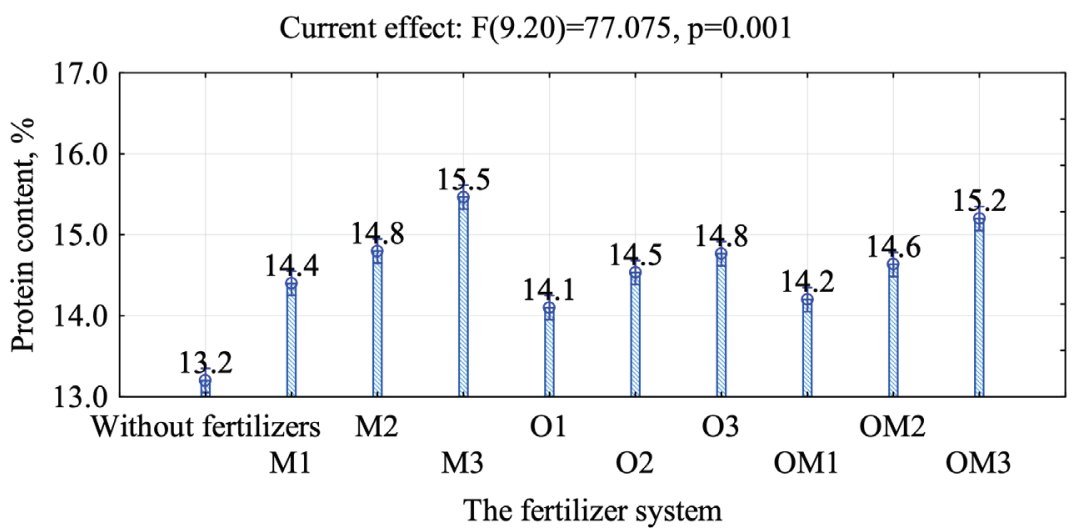

Figure 2. Protein content in spring triticale grain depending on the fertilizer and trial year, \%: Without fertilizer control; $\mathrm{M} 1-\mathrm{N}_{45} \mathrm{P}_{45} \mathrm{~K}_{45}, \mathrm{M} 2-\mathrm{N}_{90} \mathrm{P}_{90} \mathrm{~K}_{90}, \mathrm{M} 3-\mathrm{N}_{135} \mathrm{P}_{135} \mathrm{~K}_{135}, \mathrm{O} 1$ - Manure 9 t, $\mathrm{O} 2$ - Manure 13.5 t, O3 - Manure $18 \mathrm{t}$, OM1 - Manure $4.5 \mathrm{t}+\mathrm{N}_{23} \mathrm{P}_{34} \mathrm{~K}_{18}, \mathrm{OM} 2$ - Manure $9 \mathrm{t}+\mathrm{N}_{46} \mathrm{P}_{68} \mathrm{~K}_{36}, \mathrm{OM} 3$ - Manure $13.5 \mathrm{t}+\mathrm{N}_{69} \mathrm{P}_{102} \mathrm{~K}_{54}$.

cereals in field crop rotation did not affect the efficiency of fertilizer (Babulicova, 2014; Terzic et al., 2018).

Different fertilizer systems in the field crop rotation had different effects on the protein content of spring triticale grain (Figure 2).
Thus, in 2007 this indicator was significantly affected by crop rotation saturation of $\mathrm{N}_{00} \mathrm{P}_{90} \mathrm{~K}_{90}$ (M2), $\mathrm{N}_{135} \mathrm{P}_{135} \mathrm{~K}_{135}(\mathrm{M} 3)$ and Manure $9 \mathrm{t}+\mathrm{N}_{46} \mathrm{P}_{68} \mathrm{~K}_{36}$ (OM2), Manure $13.5 \mathrm{t}+\mathrm{N}_{69} \mathrm{P}_{102} \mathrm{~K}_{54}(\mathrm{OM} 3)$, as well as the variant with the highest manure saturation (O3). 
The protein content in these variants increased by $3-7 \%$ compared to areas without fertilizers. In 2008 , all levels of crop rotation saturation with mineral and organo-mineral fertilizers significantly increased the protein content. It should be noted that the highest (15.8-16.0\%) indicator was in $\mathrm{N}_{135} \mathrm{P}_{135} \mathrm{~K}_{135}$ (M3) and Manure $13.5 \mathrm{t}+\mathrm{N}_{69} \mathrm{P}_{102} \mathrm{~K}_{54}$ (OM3) variants. Under the organic fertilizer system, the protein content significantly increased by $4-9 \%$ at the second and third levels of manure saturation. In 2009, all levels of saturation and fertilizer systems in the field crop rotation significantly increased the protein content in grain. However, the mineral and organo-mineral fertilizer system had the greatest effect. Thus, the protein content increased by $9-17 \%$ for the mineral, by $8-15 \%$ for the organo-mineral and by $7-12 \%$ for the organic fertilizer system.

The research results show that the improvement of mineral nutrition, especially nitrogen one, contributes to increase the grain protein content. Researches by scientists (Jaśkiewicz \& Szczepanek, 2018) confirm this pattern. In addition, they note a significant effect of weather conditions of the growing season (precipitation and air temperature) on the content of nitrogencontaining compounds in the grain. The fall of more precipitation in 2008-2009, provided that the mineral nutrition of spring triticale plants improved, contributed to an increase in grain yield with an increase in protein content. This tendency was found in their researches by scientists studying the features of nitrogen nutrition of different triticale varieties (Lalević et al., 2019).

Spring triticale cultivation with long-term saturation of crop rotation with mineral fertilizers is environmentally safe, as confirmed by previous researches (Hospodarenko et al., 2019). The obtained research results can be used for the spring triticale variety 'Kharkiv Hlibodar' or varieties of this type. In addition, it can be grown on soils with medium and high fertility, as it has a high reaction to it. For other varieties or types of crop rotation it is necessary to conduct separate researches.

The organic fertilizer system had less effect on the protein content, as manure nutrients were first used by sugar beet plants and then by spring triticale. In addition, the nutrients were in organic form. During the heading growth stage - grain maturation, this process was weakened by the lack of moisture in the upper soil layer and high temperature. Statistically significant $(\mathrm{p} \leq 0.05)$ studied factors (fertilizer system, year) influenced the formation of yield and protein content in spring triticale grain. The power of effect was high for both factors. However, the formation of spring triticale grain yield was most influenced by the factor of the year, and less by the fertilizer system. The effect of these factors on the protein content was almost the same. This indicates that the effectiveness of spring triticale fertilizer depends on the weather conditions of the growing season. The protein content in the grain of spring triticale under such conditions varies less from weather conditions.

\section{Conclusions}

The long-term use of fertilizers in the field crop rotation under mineral, organic and organo-mineral systems significantly influenced the formation of spring triticale crop. In conditions of high air temperature and lack of soil moisture, mineral and organo-mineral fertilizer systems are preferred. In conditions with sufficient rainfall, all studied fertilizer systems are highly efficient. Spring triticale variety 'Kharkiv Hlibodar' has the high reaction to fertilizers, as grain yield increases from 6.3-6.6 (control) to 9.0-9.5 t ha ${ }^{-1}(p \leq 0.05)$. Mineral and organo-mineral fertilizer systems have the greatest effect on protein content. In conditions of sufficient moisture, all levels of the mineral and organo-mineral fertilizer systems significantly increase the protein content in spring triticale grain. In arid conditions, saturation of crop rotation area of $\mathrm{N}_{90} \mathrm{P}_{90} \mathrm{~K}_{90}(\mathrm{M} 2), \mathrm{N}_{135} \mathrm{P}_{135} \mathrm{~K}_{135}$ (M3) and Manure $9 t+\mathrm{N}_{46} \mathrm{P}_{68} \mathrm{~K}_{36}$ (OM2), Manure $13.5 \mathrm{t}+\mathrm{N}_{69} \mathrm{P}_{102} \mathrm{~K}_{54}(\mathrm{OM} 3)$ is preferred. The organic fertilizer system has less effect on this indicator. It should be noted that spring triticale is well reactive with fertilizers, as the protein content increases from $13.2-14.0$ to $15.2-16.0 \%(p \leq 0.05)$ depending on the fertilizer system. The high effect of fertilizer system and year factors on yield and protein content in triticale grain was established. It should be noted that the grain yield of spring triticale varies most from the weather conditions of the growing season.

\section{References}

Babulicová, M. (2014). The influence of fertilization and crop rotation on the winter wheat production. Plant Soil Environ. 60(7), 297-302.

Jaśkiewicz, B., \& Szczepanek, M. (2018). Amino acids content in triticale grain depending on meteorological, agrotechnical and genetic factors. In Annual $24^{\text {th }}$ International Scientific Conference Research for Rural Development 2018 (pp. 28-34), Vol. 2, Jelgava, Latvia: Latvia University of Life Sciences and Technologies. DOI: 10.22616/rrd.24.2018.047.

Darguza, M., \& Gaile, Z. (2020). The effect of crop rotation and soil tillage on winter wheat yield. In Annual $26^{\text {th }}$ International Scientific Conference Research for Rural Development 2020 (pp. 14-21), Vol. 35, Jelgava, Latvia: Latvia University of Life Sciences and Technologies. DOI: 10.22616/rrd.26.2020.002. 
Dekić, V., Milovanović, M., Popović, V., Milivojević, J., Staletić, M., Jelić, M., \& Perišić V., (2014). Effects of fertilization on yield and grain quality in winter triticale. Rom. Agric. Res. 31, 175-183.

Furman, B.J. (2016). Triticale. Reference Module in Food Science. 3, 298-303. DOI: 10.1016/B978-0-08100596-5.00019-6.

Hospodarenko, H., Prokopchuk, I., Nikitina, O., \& Liubych, V. (2019). Assessment of the contamination level of a podzolized chernozem with nuclides in a long-term land use. Agriculture. 65(3), 128-135. DOI: 10.2478/AGRI-2019-0013.

Karl, F. (2017). Technology of main ingredients - water and flours. Wafer and Waffle. 15-121. DOI: 10.1016/ B978-0-12-809438-9.00002-8.

Kiseleva, M.I., Kolomiets, T.M., Pakholkova, E.V., Zhemchuzhina, N.S., \& Lubich, V.V. (2016). The differentiation of winter wheat (Triticum aestivum L.) cultivars for resistance to the most harmful fungal pathogens. Agricultural biology. 51 (3), 299-309. DOI: 10.15389/AGROBIOLOGY.2016.3.299RUS.

Lalević, D., Biberdžić, M., Ilić, Z., Milenković, L., Tmušić, N., \& Stojiljković, J. (2019). Effect of cultivar and increased nitrogen quantities on some productive traits of triticale. Agriculture \& Forestry. 65(4), 127-136. DOI: 10.17707/AgricultForest.65.4.11.

Litke, L., Gaile, Z., \& Ruža, A. (2017). Nitrogen fertilizer influence on winter wheat yield and yield components depending on soil tillage and forecrop. In Annual $23^{\text {th }}$ International Scientific Conference Research for Rural Development 2017 (pp. 54-61), Vol. 2, Jelgava, Latvia: Latvia University of Life Sciences and Technologies. DOI: 10.22616/rrd.23.2017.049.

Liubych, V., Novikov, V., Zheliezna, V., Prykhodko, V., Petrenko, V., Khomenko, S., Zorunko, V., Balabak, O., Moskalets, V., \& Moskalets, T. (2020). Improving the process of hydrothermal treatment and dehulling of different triticale grain fractions in the production of groats. Eastern-European Journal of Enterprise Technologies. 3(105), 55-65. DOI: 10.15587/1729-4061.2020.203737.

Liubych, V.V. (2019). Key properties of spring triticale grain depending on the dose and timing of the nitrogen application. Collected Works of Uman National University of Horticulture. 95, 30-44. DOI: 10.31395/24158240-2019-95-1-30-44.

Nikolic, O., Zivanovic, T., Jelic, M., \& Djalovic, I. (2012). Interrelationships between grain nitrogen content and other indicators of nitrogen accumulation and utilization efficiency in wheat plants. Chilean J. Agric. Res. 72(1), 111-116.

Novak, L., Liubych, V., Poltoretskyi, S., \& Andrushchenko, M. (2019). Technological indices of spring wheat grain depending on the nitrogen supply. Modern Development Paths of Agricultural Production: Trends and Innovations. 753-761. DOI: 10.31388/2220-8674-2019-1-55.

Obour, A.K., Holman, J.D., \& Schlegel, A.J. (2020). Spring triticale forage responses to seeding rate and nitrogen application. Agrosyst Geosci Environ. 3, 1-7. DOI: 10.1002/agg2.20053.

Osokina, N., Liubych, V., Novikov, V., Leshchenko, I., Petrenko, V., Khomenko, S., Zorunko, V., Balabak, O., Moskalets, V., \& Moskalets, T. (2020). Effect of Electromagnetic Irradiation of Emmer Wheat Grain on the Yield of Flattened Wholegrain Cereal. Eastern European Journal of Enterprise Technologies. 5(108), 40-51. DOI: 10.15587/1729-4061.2020.217018.

Salmon, D.F., Mergoum, M., \& Macpherson, H. (2004). Triticale production and management. FAO Plant Production and Protection Paper. 179, 27-36. ISBN 92-5-105182-8.

Terzic, D., Djekic, V., Jevtic, S., Popovic, V., Jevtic, A., Mijajlovic, J., \& Jevtic, A. (2018). Effect of long term fertilization on grain yield and yield components of winter triticale The Journal of Animal \& Plant Sciences. 28(3), 830-836.

Wrigley, C., \& Bushuk, W. (2017). Triticale: Grain-Quality Characteristics and Management of Quality Requirements. In C, Wrigley, I.L., Batey \& D. Miskelly (Eds.), Cereal Grains: Assessing and Managing Quality: Second Edition, (pp. 179-194). Elsevier Acquires Woodhead Publishing. DOI: 10.1016/B978-008-100719-8.00008-5. 